\title{
MANAJEMEN SUPERVISI AKADEMIK KEPALA MADRASAH
}

\author{
Azis Iskandar \\ Universitas Islam Negeri Sunan Gunung Djati Bandung \\ Email: azisiskandar72@gmail.com
}

\begin{abstract}
ABSTRAK
Penelitian ini bertujuan untuk mengetahui manajemen supervisi akademik kepala madrasah, perencanaan supervisi akademik kepala madrasah, pelaksanaan supervisi akademik kepala madrasah, dan evaluasi serta tindak lanjut supervisi akademik kepala madrasah. Penelitian ini menggunakan pendekatan kualitatif. Teknik pengumpulan data melalui observasi, wawancara, dokumentasi. Subjek penelitian adalah kepala madrasah dan guru. Hasil penelitian menunjukkan: profil pendidikan Madarsah Aliyah Negeri 2 Ciamis; penyusunan program supervisi akademik disusun pada awal tahun ajaran dengan mengikutsertakan guru-guru. Program supervisi akademik disusun berdasarkan permasalahan yang dihadapi guru tentang pembelajaran serta menyesuaikan dengan kebutuhan guru; pelaksanaan supervisi akademik sesuai dengan program yang telah disusun dengan menggunakan beberapa teknik supervisi diantaranya teknik individual dan teknik kelompok; evaluasi dilakukan dengan melihat hasil program perencanaan dan pelaksanaan supervisi akademik yang diterapkan dan tindak lanjut yang dilakukan kepala madrasah dengan memberikan pembinaan pada guru yang belum memenuhi standar serta penghargaan pada guru yang memenuhi standar; dan faktor pendukung dan penghambat supervisi akademik kepala madrasah. Berdasarkan hasil penelitian tersebut, maka pelaksanaan supervisi akademik kepala madrasah dalam meningkatkan kinerja guru pada Madrasah Aliyah Negeri 2 Ciamis belum terlaksana dengan baik dalam peningkatan kinerja guru.
\end{abstract}

Kata kunci: Manajemen, Supervisi Akademik, Kepala Madrasah

\section{ABSTRACT}

This study aims to determine the management of headmaster academic supervision, headmaster academic supervision planning, the implementation of academic supervision of the principal, and the evaluation and follow-up of the academic supervision of the principal. This study uses a qualitative approach. Data collection techniques through observation, interviews, documentation. The research subjects were the head of the madrasa and the teacher. The results of the study showed: profile of education in Ciamis 2 Islamic Senior High School preparation of academic supervision programs arranged at the beginning of the 
school year by including teachers. Academic supervision program is arranged based on the problems faced by the teacher about learning and adjusting to the needs of the teacher; implementation of academic supervision in accordance with programs that have been prepared using several supervision techniques including individual techniques and group techniques; evaluation is carried out by looking at the results of the planning and implementation of academic supervision programs implemented and follow-up conducted by the headmaster by providing guidance to teachers who have not met standards and awards to teachers who meet the standards; and factors supporting and inhibiting the academic supervision of the headmaster. Based on the results of these studies, the implementation of the headmaster's academic supervision in improving teacher performance in Ciamis 2 Islamic Senior High School has not been well implemented in improving teacher performance.

Key words: Management, Academic Supervision, Head Master

\section{PENDAHULUAN}

Salah satu usaha yang digunakan untuk mewujudkan manusia seutuhnya ialah pendidikan. Oleh karena itu, Pendidikan Nasional yang berdasarkan Pancasila bertujuan untuk meningkatkan ketakwaan kepada Tuhan Yang Maha Esa kecerdasan, keterampilan, mempertinggi budi pekerti, memperkuat kepribadian, mempertebal semangat kebangsaan, dan cinta tanah air agar menumbuhkan manusia-manusia pembangunan yang dapat membangun dirinya sendiri serta bersama-sama bertanggung jawab atas pembangunan bangsa (Mustafid dkk., 2016)

Pendidikan dalam praktiknya memerlukan peran kepala madrasah agar mampu mengelola proses pendidikan dengan efektif dan efisien. Pengelolaan dalam disiplin ilmu sering disebut manajemen. Manajemen menurut G.R. Terry dalam adalah proses yang terdiri dari perencanaan, pengorganisasian, pelaksanaan, dan pengawasan untuk mencapai tujuan (Jahari, 2013).

Keberhasilan membangun manajemen lembaga merupakan kunci utama dari majunya mutu pendidikan dilembaga tersebut. Mutu pendidikan dapat diukur dari salah satu aspek yaitu supervisi akademik. Supervisi akademik merupakan kegiatan terencana pada aspek kualitatif sekolah dengan membantu guru melalui dukungan dan evaluasi pada proses pembelajaran agar dapat meningkatkan hasil belajar siswa (Dibyantoro, 2017). Pelaksanaan supervisi akademik memerlukan perencanaan yang matang sehingga kepala madrasah mampu menerapkan prinsip-prinsip supervisi akademik dengan baik (Leniwati \& Arafat, 2017).

Supervisi akademik tidak terlepas dari penilaian kinerja guru dalam mengelola pembelajaran (Prasojo \& Sudiyono, 2015). Supervisi akademik bertujuan memantau guru dalam melaksanakan kinerja supaya bekerja secara profesional. Pemantauan guru dilakukan oleh kepala madrasah dalam kegiatan supervisi akademik (Maralih, 2014). Pelaksanaan supervisi merupakan tugas kepala sekolah untuk melakukan pengawasan terhadap guru dan pegawai sekolahnya, kegiatan ini juga mencakup penelitian, penentuan berbagai kebijakan yang diperlukan, dan pemberian jalan keluar bagi permasalahan yang dihadapi oleh seluruh pegawainya (Nabila, 2018). Namun dalam kenyataanya 
sering dijumpai adanya kepala madrasah melaksanakan supervisi akademik hanya datang ke madrasah dengan membawa instrumen pengukuran kinerja. Kemudian masuk ke kelas melakukan pengukuran terhadap kinerja guru yang sedang mengajar. Setelah itu, selesailah tugasnya, seakan-akan supervisi akademik sama dengan pengukuran kinerja guru dalam proses pembelajaran.

Perencanaan program supervisi akademik adalah penyusunan dokumen perencanaan pemantauan, serangkaian kegiatan membantu guru mengembangkan kemampuannya, mengelola proses pembelajaran untuk mencapai tujuan pembelajaran. Keefektifan supervisi memerlukan satu program yang memuat berbagai aktivitas atau kegiatan yang akan dikerjakan oleh supervisor. Program dibutuhkan untuk menggambarkan apa yang akan dilakukan, cara melakukan, waktu pelaksanaan dan cara mengukur keberhasilan pelaksanaannya (Prasojo \& Sudiyono, 2015).

Dengan demikian penyusunan rencana supervisi akademik merupakan hal penting, yang dilakukan oleh kepala sekolah dalam rangka meningkatkan kompetensi guru dalam mengelola proses pembelajaran demi tercapainya tujuan pembelajaran (Zulfikar dkk., 2017). Perencanaan supervisi akademik meliputi sejumlah hal yang saling berkaitan satu dengan yang lainnya, yaitu terkait dengan pelaksanaan kurikulum, persiapan pelaksanaan dan penilaian pembelajaran oleh guru, pencapaian standar kompetensi kelulusan, standar proses, standar isi, dan peraturan pelaksanaannya, serta peningkatan mutu pembelajaran (Anissyahmai dkk., 2017).

Pelaksanaan supervisi akademik mempunyai langkah-langkah yang dapat ditempuh oleh kepala madrasah yaitu mengidentifikasi masalah, menganalisis masalah, merumuskan cara-cara pemecahan masalah, implementasi pemecahan masalah, dan evaluasi dan tindak lanjut (Syukri dkk., 2015). Pelaksanaan supervisi tidak hanya mendatangi guru dan memeriksa berkas atau melihat pelaksanaan mengajar dikelas, tetapi perlu secara drastis memikir ulang model supervisi yang ada selama ini untuk mencapai hasil pembelajaran yang baik (Nurfatah \& Rahmad, 2018).

Pelaksanaan supervisi pendidikan yang perlu diperhatikan adalah IImiah (scientific) yaitu sistematis yang berarti dilaksanakan secara teratur, terencana, dan berkelanjutan, dan juga objektif yaitu data yang diperoleh berdasarkan hasil observasi nyata (Sagala, 2012). Dalam pelaksanakan supervisi akademik, pengawas sekolah harus mengetahui dan memahami serta melaksanakan teknik-teknik dalam supervisi. dalam kegiatan supervisi pengajaran, guru-guru tidak dianggap sebagai subyek pasif, melainkan diperlakukan sebagai partner bekerja yang memiliki ide-ide, pendapat-pendapat, dan pengalamanpengalaman yang perlu didengar dan dihargai serta diikutsertakan di dalam usaha-usaha perbaikan pendidikan, terutama perbaikan proses pembelajaran di madrasah (Subaidi, 2019). Berbagai teknik yang dapat digunakan oleh pengawas sekolah baik secara kelompok maupun secara perorangan adalah dengan cara langsung bertatap muka dan cara tak langsung bertatap muka atau melalui media komunikasi (Messi dkk., 2018).

Evaluasi adalah suatu tindakan pengujian terhadap manfaat (worth), kualitas, kebermaknaan, jumlah, kadar atau tingkat, tekanan atau kondisi dari beberapa perbandingan situasi, (hasil evaluasi dari beberapa situasi yang sama 
yang digunakan sebagai standar perbandingan), yang kualitasnya telah diketahui dengan baik (Anissyahmai dkk., 2017).

Hasil supervisi perlu ditindak lanjuti agar memberikan dampak yang nyata untuk meningkatkan profesionalisme guru. Tindak lanjut tersebut dapat berupa penguatan dan penghargaan kepada guru yang telah memenuhi standar, teguran yang bersifat mendidik diberikan kepada guru yang belum memenuhi standar, dan guru diberi kesempatan untuk mengikuti pelatihan/penataran lebih lanjut. Kegiatan tindak lanjut supervisi akademik sasaran utamanya adalah kegiatan belajar mengajar (Prasojo \& Sudiyono, 2015).

Manajemen supervisi akademik kepala madrasah di implementasikan di MAN 2 Ciamis dengan program supervisi akademik yang ditetapkan oleh kepala madrasah. Oleh karena itu, penelitian dilakukan di MAN 2 Ciamis. Tujuan penelitian ini untuk mengetahui manajemen supervisi akademik kepala madrasah yang akan dilihat melalui perencanaan, pelaksanaan, evaluasi dan tindak lanjut, serta faktor pendukung dan penghambat di MAN 2 Ciamis.

\section{METODE}

Jenis penelitian yang digunakan dalam penelitian ini adalah penelitian kualitatif dengan metode deskriptif. Hasil penelitian akan dijelaskan dengan mendeskripsikan manajemen supervisi akademik Kepala MAN 2 Ciamis. Penelitian dilakukan dengan beberapa tahap, diantaranya penyusunan proposal, perizinan, pengumpulan data, analisis data, dan penulisan laporan penelitian. Sumber data pokok penelitian ini adalah kepala madrasah, wakil kepala madrasah, dan guru. Prosedur penelitian ini diawali dengan observasi awal, kemudian paparan masalah melalui kajian teori, menyusun instrument, dan pengumpulan data. Data yang telah terkumpul kemudian diolah melalui beberapa teknik analisis data dan terkahir membuat kesimpulan. Pada penelitian di MAN 2 Ciamis menggunakan tiga teknik pengumpulan data yakni observasi, wawancara, dan studi dokumentasi lapangan. Kemudian untuk memeriksa keabsahan data dilakukan teknik triangulasi.

\section{HASIL DAN PEMBAHASAN}

\section{Profil Kepala MAN 2 Ciamis}

Manajemen supervisi akademik kepala madrasah di MAN 2 Ciamis dilakukan oleh kepala madrasah dibantu oleh wakil kepala madrasah dan guru senior. Kepala MAN 2 Ciamis yaitu Drs. H. Kasrodin, M.M.Pd kerap di panggil dengan sapaan Pak Kasro lahir di Tasikmalaya, 10 April 1966 tepatnya di kampung simpang RT 010 RW 005 Desa Simpang Kecamatan Bantarkalong Kabupaten Tasikmalaya Provinsi Jawa Barat.

Setelah lulus dari Perguruan Tinggi Insitut Agama Islam Cipasung Tasikmalaya (IAIC) pada tahun 1994 Pak Kasro mengajar di MAN Bantarkalong sebagai guru dan wakil kepala madrasah samapai dengan tahun 2009. Selain mengajar di MAN Bantarkalong, beliau menjabat juga di MAN Cibadak sebagai kepala madrasah dari tahun 2009 samapai dengan tahun 2012. Dari tahun 2012 sampai sekarang beliau menjabat sebagai Kepala Madrasah di MAN 2 Ciamis. Pak kasro melanjutkan S2 di Sekolah Tinggi Manajemen Insitut Manajemen Newport Internasional Jakarta (STM IMNI Jakarta) lulus pada tahun 2015. 
Di lembaga pendidikan, kepala madrasah adalah seorang pemimpin yang mengarahkan, mempengaruhi, dan mengendalikan seluruh potensi madrasah secara sistemik dan terprogam dalam rangka mencapai tujuan operasional. Disamping kemampuan memimpin tersebut seorang kepala madrasah juga harus memiliki perilaku yang dapat mendorong kinerja bawahannya, terutama para guru dengan menunjukan rasa bersahabat, dekat dan penuh pertimbangan terhadap para guru, baik secara individu maupun kelompok.

Jadi keberhasilan dan kesuksesan suatu lembaga pendidikan sangat tergantung pada kepemimpinan kepala madrasah yang sedang memimpin. Karena kepala madrasah sebagai pemimpin di lembaganya, maka kepala madrasah harus mampu membawa lembaganya kearah tercapainya tujuan yang telah ditetapkan, dia harus mampu melihat adanya perubahan serta mampu melihat masa depan dalam kehidupan globalisasi yang lebih baik.

\section{Perencanaan Supervisi Akademik}

Sebagaimana diatur dalam Peraturan Mentri Pendidikan Nasional No 13 tahun 2007 tentang Standar Kepala Sekolah/Madrasah. Salah satu kompetensi yang harus dijalankan oleh kepala madrasah dalam hal kompetensi supervisi adalah membina para guru dalam pengelolaan dan administrasi kelas berdasarkan manajemen peningkatan-peningkatan mutu pendidikan di madrasah. Kepala madrasah selaku supervisor pendidikan memiliki fungsi mengarahkan, membimbing dan mengawasi seluruh kegiatan pendidikan dan kegiatan pembelajaran yang dilaksanakan guru.

Dari hasil penelusuran peneliti melalui wawancara dengan kepala MAN 2 Ciamis dapat diketahui bahwa perencanaan supervisi akademik disusun ketika rapat atau musyawarah di awal tahun pelajaran, dengan menyusun progam jangka panjang dan jangka pendek. Dalam merencanakan supervisi akademik, kepala madrasah membuat tim supervisor yang terdiri dari para wakil kepala madrasah serta membuat gambaran pelaksanaan supervisi yang akan dilakukan setiap semesternya. Supervisi akademik di MAN 2 Ciamis sudah berjalan dengan baik dan bagus karena setiap semesternya ada perubahan guru-guru dalam mengajar setelah dilaksanakn supervisi.

Supervisi perlu disusun oleh kepala madrasah dan disosialisasikan kepada guru melalui rapat sekolah, sehingga guru-guru mengetahui dan memahami maksud dan tujuan dari program supervisi tersebut. Dalam menyusun program supervisi akademik, kepala madrasah juga dapat melibatkan guru-guru terutama sekali dalam menentukan jadwal supervisi. Dengan demikian, guru ikut berpartisipasi dalam kegiatan tersebut dan turut bertanggung jawab atas pelaksanaannya. Kemudian pada sisi lain guru dapat mengetahui dan memahami supervisi akademik yang dilakukan sejak dini, sehingga sudah dapat mempersiapkan diri untuk melengkapi administrasi kelas maupun adminintrasi pembelajaran dan perangkat-perangkat lainnya. Dengan adanya kebersamaan dalam menyusun suatu program, maka semua pihak akan merasa dihargai dan dapat menghilangkan kesalahpahaman antara kepala madrasah dengan guru. Untuk itu sangat perlu disusun dan disosialisasikan program supervisi sebagai pembinaan awal terhadap guru-guru yaitu menyampaikan atau menjelaskan tentang pengertian, tujuan dan manfaat dari supervisi akademik. 
Penyusunan perencanaan supervisi akademik dilakukan setiap awal tahun ajaran baru. Hal tersebut dilakukan dengan melibatkan wakil kepala sekolah dan guru-guru. Setiap guru akan disupervisi dua kali dalam satu semester atau empat kali dalam satu tahun ajaran. Ruang lingkup dalam perencanaan supervisi akademik yang dilakukan oleh Kepala MAN 2 Ciamis adalah pengembangan kurikulum atau silabus, pelaksanaan pembelajaran yang baik, dan pencapaian kriteria ketuntasan minimal. Sasaran dalam perencanaan supervisi akademik kepala sekolah adalah kemampuan guru dalam mengelola pembelajaran, mulai dari merencanakan, melaksanakan, dan mengevaluasi hasil belajar siswa.

Dalam konteks merencanakan program supervisi, Kepala MAN 2 Ciamis menjelaskan bahwa ada rencana yang diagendakan kepala madrasah sebagai supervisor, diantaranya adalah yang pertama, merencanakan administrasi lengkap MAN 2 Ciamis dan guru yang akan di supervisi oleh kepala madrasah. Kedua, menyusun jadwal kegiatan tahunan, bulanan dan mingguan. Disinilah problem ditemukan, di mana peneliti cukup kesulitan untuk mendapatkan gambaran sebenarnya rencana kegiatan supervisi akademik kepala madrasah dalam meningkatkan mutu pembelajaran untuk tahunan, bulanan dan mingguan. Namun menurut penuturan Kepala MAN 2 Ciamis bahwasannya supervisi akademik yang dilakukan yaitu dalam satu tahun dilaksanakan sekali dalam setiap semesternya, yang mana adanya supervisi akademik ini adalah sebagai proses dalam menanamkan kinerja guru dan kompetensi dalam mengajar agar lebih baik. Oleh karena itu, kepala madrasah dalam menerapkan supervisi akademik hanya sebatas mengagendakan adanya supervisi dan tinggal bagaimana mengapilkasikannya saja. Namun, dalam penerapannya dilapangan biasanya tidak sesuai dengan yang sudah terjadwal atau dalam hal ini dilaksanakan secara mendadak dan kondusional. Ketiga, melakukan koordinasi dan kerjasama dengan dinas-dinas terkait seperti dengan Kementrian Agama dan juga Kementrian Pendidikan terkait, dalam melakukan kegiatan supervisi akademik. Keempat, melakukan kunjungan kelas yang bertujuan untuk melakukan pengamatan terhadap seluruh kegiatan belajar mengajar di dalam ruang kelas pada setiap guru mata pelajaran (untuk lebih jelasnya terkait dengan kegiatan pengawas dalam kunjungan kelas dapat dilihat pada format atau isnstrumen kunjungan kelas).

Supervisi akademik kelima yang dilakukan oleh Kepala MAN 2 Ciamis adalah mengadakan konsultasi perorangan yang dipandang perlu. Untuk kasus ini pihak madrasah dengan team supervisor menindak lanjuti dengan berkoordinasi dengan supervisor dari pusat baik Kementerian Agama maupun Dinas Pendidikan. Keenam, mengadakan konsultasi pengembangan kelompok kerja guru dan pembinaan guru secara kolektif yakni menentukan hari dan waktu pembinaan, menyiapkan materi pembinaan, menyiapkan pembinaan dan informasi baru. Ketujuh, memantau perkembangan pelaksanaan kurikulum, yakni memantau pelaksanaan kurikulum madrasah, memantau pencapaian target kurikulum oleh guru, memantau hasil belajar peserta didik setiap akhir semester dan akhir taun. Kedelapan, mengevaluasi kegiatan guru, yakni mengadakan kunjungan kelas, dan membuat rekap data guru. Kesembilan, membantu penyelenggaraan pembinaan guru yakni memberikan bimbingan yang terkait dengan tugas guru, memberikan bimbingan yang terkait dengan sikap dan 
profesionalitas guru, dan mengadakan kordinasi dengan guru dan menyampaikan informasi kepada para guru. Kesepuluh, mengadakan konsultasi/konsolidasi dengan sesama pengawas yang salah satu tujuannya adalah untuk memperluas dan memperdalam wawasan kemampuan, dan kerjasama, mewujudkan kesatuan sikap dan tindakan dalam melaksanakan peraturan-peraturan yang berlaku, serta membicarakan, mengusahakan dan mengatasi kendala-kendala yang ditemui dalam pelaksanaan tugasnya sebagai kepala madrasah

Jadwal kunjungan kelas dalam program supervisi akademik disusun pada awal tahun pelajaran, maka bukan tidak mungkin ada kegiatan lain yang bersamaan, apalagi hal-hal yang bersifat mendadak. Untuk itu perlu harus ada pengertian dan kerja sama yang baik diantara sesama guru dan dengan kepala madrasah, sehingga dapat dibicarakan lagi untuk kegiatan lanjutannya atau penggantinya. Karena supervisi akademik bukan hanya untuk memeriksa atau melihat kelengkapan administrasi saja, tetapi lebih dari itu yakni kemampuan guru dalam mengelola pembelajaran di kelas. Namun demikian semakin rinci dan operasional suatu program yang sudah di rencanakan tentu akan semakin baik karena akan membantu dan mempermudah supervisor didalam melaksanakan kegiatan-kegiatan yang akan dilakukannya.

Jadi perencanaan supervisi akademik Kepala MAN 2 Ciamis menyusun jadwal dan program supervisi akademik dilaksanakan setiap awal semester yang melibatkan wakil kepala sekolah bidang kurikulum. Bahwasannya perencanaan supervisi akademik disusun ketika rapat atau musyawarah di awal tahun tahun pelajaran, dengan menyusun progam jangka panjang dan jangka pendek. Dalam merencanakan supervisi akademik, kepala madrasah membuat team supervisor yang terdiri dari para wakil kepala madrasah serta membuat gambaran pelaksanaan supervisi yang akan dilakukan setiap semesternya. Supervisi akademik di MAN 2 Ciamis sudah berjalan dengan baik dan bagus karena setiap semesternya ada perubahan guru-guru dalam mengajar setelah dilaksanakn supervisi. Supervisi akademik direncanakan dengan menggunakan teknik individu dan kelompok.

\section{Pelaksanaan Supervisi Akademik}

Setelah menyusun perencanaan rogram supervisi akademik, maka selanjutnya memasuki tahap pelaksanaannya. Pelaksanaan akan berjalan baik bila segala rencana yang telah disusun sudah dipersiapkan dengan baik. Sasaran kegiatan supervisi akademik intinya adalah untuk mengembangkan dan meningkatkan proses pembelajaran yang didalamnya terdiri dari sistem pembelajaran, metode pembelajaran, media/alat pembelajaran, penyusunan perangkat pembelajaran berupa silabus dan RPP, dan evaluasi hasil pembelajaran. Dengan demikian berarti esensi supervisi akademik itu sama sekali bukan menilai unjuk kerja guru dalam mengelola proses pembelajaran, melainkan membantu guru mengembangkan dan meningkatkan kompetensi pedagogik serta profesionalismenya dalam proses belajar mengajar didalam dunia pendidikan.

Di lihat dari hasil transkip pernyataan kepala madrasah yang menyatakan bahwa ada beberapa gabungan pelaksanaan manajemen supervisi yang dilakukannya adalah yang pertama biasanya mengadakan supervisi 
pembelajaran yang meliputi administrasi guru yaitu kelengkapan guru dalam membuat perangkat belajar seperti bahan ajar/materi, silabus, RPP, program semester, program tahunan dan sebagainya. Kontrol administrasi bagi guru juga biasanya dilakukan pada awal tahun ajaran baru. Yang kedua, melakukan supervisi kelas yang mana biasanya dalam melakukan supervisi ini didampingi oleh team supervisor yang dibentuk oleh kepala madrasah dan juga biasanya menjalin kerjasama dengan Kementerian Agama dan Dinas Pendidikan. Dan yang ketiga dengan cara menilai kinerja guru dalam pengelolaan kelasnya dengan melakukan riview dalam memperbaiki hasil dari supervisi sebagai bahan koreksi bagi guru kedepannya. Kemudian adanya masukan dari pengawas sebagai bahan pengkoreksian bagi masing-masing guru agar kedepannya dituntut untuk lebih memperbaiki proses pembelajaran dan administrasinya. Lalu, berkaitan dengan supervisi akademik dalam meningkatkan kompetensi pedagogiknya biasanya guru-guru dikirimkan untuk mengikuti penataran, diklat, workshop dan seminar baik dari madrasah ataupun instansi terkait sebagai penunjang pengembangan diri guru.

Dari pernyataan kepala madrasah menunjukkan, bahwa pelaksanaan supervisi akademik tidak selalu dilaksanakan ketika guru sedang mengajar saja. Banyak cara yang bisa dijadikan acuan dalam menjalankan supervisi akademik. Terkadang cara yang digunakan kepala madrasah adalah cara yang langsung dijadwalkan dengan pelaksanaan evaluasi. Kelengkapan administrasi harus dipegang oleh semua guru sebagai kewajiban yang di emban oleh para guru. Akan tetapi lebih dari itu juga, perangkat pembelajaran merupakan dasar utama kelayakan mengajar guru agar materi yang disampaikan sesuai dengan apa yang direncanakan tidak melebar dan dapat dimengerti oleh peserta didik.

Sedangkan hasil wawancara bersama wakil kepala madrasah bagian kurikulum menjelaskan bahwa pelaksanaan supervisi akademik dilakukan sesuai perencanaan yang disusun oleh kepala madrasah dan team supervisor. Pelaksanaan supervisi dilakukan dengan kondisional walaupun ketika perencanaan sudah tersusun di panduan progam supervisi akademik. Team supervisor melakukan penilaian administrasi berupa RPP dan silabus sebelum terjun ke lapangan untuk melihat proses pembelajaran. Selain itu, setiap hari selalu ada pengontrolan dari team supervisor yaitu para wakil kepala madrasah untuk mengecek kehadiran para guru dalam mengajar dikelas dan biasanya dilakukan ketika pagi, setelah istrahat dan setelah shalat dhuhur.

Kunjungan kelas adalah teknik pembinaan terhadap para guru oleh kepala madrasah, pengawas dan pembina lainnya dalam rangka mengamati dan memantau pelaksanaan proses kegiatan belajar mengajar sehingga memperoleh data yang akurat yang diperlukan dalam rangka pembinaan dan pengembangan terhadap guru. Tujuannya adalah semata-mata untuk melihat dan menolong guru dalam mengatasi kesulitan ketika guru mengajar dan memastikan bahwa guru sedang melaksanakan tugasnya dengan baik. Melalui kunjungan kelas ini, guruguru dibantu kepala madrasah melihat dengan jelas masalah-masalah yang mereka alami.

Sebagaimana hasil penemuan peneliti, bahwa kunjungan kelas ini, merupakan salah satu teknik yang sering digunakan kepala madrasah dalam menjalankan supervisinya. Teknik ini bentuknya adalah mengamati langsung seorang guru yang sedang mengajar di dalam kelas. Untuk mengetahui secara 
keseluruhan cara-cara guru mendidik dan mengajar, termasuk pribadi dan gaya mengajarnya. Dengan kata lain, teknik ini digunakan untuk melihat apa kekurangan dan kelebihan yang perlu diperbaiki dan ditingkatkan.

Seperti yang dikatakan oleh salah satu guru bahwa pelaksanaan supervisi akademik sebelumnya ada pemberitahuan yang dilakukan oleh kepala madrasah sebelum melakukan supervisi akademik ini biasanya teknik yang beliau lakukan adalah hal yang pertama memberitahukan kepada semua guru bahwa nanti akan diadakan supervisi baik yang dilakukan oleh pihak madrasah itu sendiri. Biasanya guru-guru mempersiapkan proses pembelajaran secara maksimal dari mulai RPP, Silabus, Media pembelajaran bahkan dari kedisiplinan dan kerapihan sehingga dengan adanya supervisi akademik sangat mempengaruhi terhadap mutu pembelajaran

Sebelum merencanakan kunjungan kelas, kepala madrasah terlebih dahulu memberitahu kepada guru-guru yang akan disupervisi. Proses pelaksanaan kunjungan kelas ini memang dilakukan secara bertahap. Artinya tidak semua guru disupervisi dan dikunjungi dalam satu waktu selesai. Karena keterbatasan waktu dari kepala madrasah. Dalam hal ini, kepala madrasah biasanya berkunjung bersama wakil kepala madrasah bidang kurikulum beserta team supervisor madrasah.

Kegiatan supervisi akademik sudah sering dilakukan oleh kepala madrasah maupun wakil kepala madrasah semua bidang. Sebelumnya ada pemberitahuan terlebih dahulu supaya guru-guru mempersiapkan proses pembelajarannya dengan maksimal dari mulai perangkat pembelajaran hingga proses pembelajaran dikelasnya.

Untuk supervisi individu dilaksanakn setahun sekali, dikarenakan sudah terpasang CCTV di setiap kelas sehingga mempermudah pengecekan guru dalam mengajar. Pelaksanaan supervisi ini tidak pasti apakah di awal semester atau diakhir semester akan tetapi sering dilaksankan di awal semester karena semester kedua banyak berbenturan dengan berbagai kegiatan, kalau tahun kemarin memang tidak terlaksana program ini dan untuk tahun ini rencana di akhir tahun.

Sebelum mengadakan supervisi individu para guru akan diberikan informasi terkait waktu dilaksanaknya supervisi, supaya para guru mempersiapkan adminstarsi yang dibutuhkan. Penilaian dilaksankan ketika pengamatan, dan penilaian ini bisa lama dilaksankannya karena dalam supervisi individu banyak aspek yang harus di nilai, akan tetapi yang paling diamati adalah penguasaan kelas, dengan indikatornya menguasai materi, menguasai model pembelajaran, mobilisasi kelas, suara dalam penyampaian dan tulisan.

Pelaksanaan supervisi individu dilakukan, akan tetapi waktu pelaksananya belum tentu. Pengembangan guru atau supervisi kelompok, di MAN 2 Ciamis berupa IKG dan workshop. Bentuknya seperti MGMP tapi pesertanya dari semua guru MAN 2 Ciamis. Informasi pelakasanaan supervisi individu atau observasi kelas biasanya diumumkan ketika ada rapat guru atau waktu IKG. Akan tetapi yang diamati dari observasi penliti bahwasanya terkadang kepala madrasah keliling di kelas-kelas, terkadang ikut bersama didalam kelas, dan sekarang lebih mudah kerena sudah ada CCTV dan pasti ada pemberian skor pada setiap proses supervisi dilakukan. 
Dalam melaksanakan program supervisi akademik yang sudah dibuat, Kepala MAN 2 Ciamis terlebih dahulu mengkomunikasikan kepada guru-guru. Program supervisi yang sudah dibuat dan akan dilaksanakan, diberitahukan kepada guru-guru terlebih dahulu, baik melalui rapat-rapat guru maupun dalam pertemuan sehari-hari. Kepala MAN 2 Ciamis menerapkan beberapa prinsip supervisi akademik, diantaranya menciptakan hubungan yang harmonis, berkesinambungan, demokratis, dan konstruktif.

\section{Evaluasi dan Tindak Lanjut Supervisi Akademik}

Tindak lanjut supervisi akademik dilakukan dengan cara mengevaluasi secara umum kepada seluruh guru-guru dalam setiap rapat tahunan, bulanan dan mingguan. Setelah kepala madrasah memperoleh hasil dari apa yang menjadi penilaian supervisi akademik dengan melakukan penilaian terhadap bahan ajar dan kunjungan kelas, dalam program mingguan ada evaluasi berupa breffing yang dilakukan setiap hari Senin. Didalam forum tersebut dijelaskan hasil dari tim supervisor tetapi tidak secara personal melainkan disebutkan kesalahankesalahan sehingga semua guru mampu mengevaluasi dirinya masing-masing.

Evaluasi supervisi kelompok biasanya dilakukan kepala madrasah pada rapat rutin bulanan, semester dan tahun baik di awal maupun di akhir tahun ajaran baru. Evaluasi melalui rapat rutin guru ini seperti yang dilakukan oleh kepala madrasah dengan memberikan motivasi, bimbingan dan arahan kepada guru dan karyawan. Dan pertemuan rutin guru ini adalah sebagai bentuk evaluasi dan supervisi akademik kepala madrasah dalam menilai dan meningkatkan kompetensi pedagogik dan kinerja guru agar lebih profesional sehingga mutu pembelajaran meningkat sesuai harapan.

Dalam pelaksanaan evaluasi ini merupakan solusi yang ditempuh kepala madrasah sebagai supervisor dalam mencari persepsi kesamaan dan pembinaan terhadap guru yang dilakukan secara berkelompok yaitu dengan cara mengadakan rapat rutinan. Namun disini juga ditemukan masalah yang disebabkan oleh lamanya tindak lanjut dari kepala madrasah yang harus menunggu evaluasi bulanan dan bahkan tahunan ini menyebabkan hasil dari tindak evaluasi masih kurang cukup efektif karena lamanya waktu setelah pelaksanaan supervisi.

Tindak lanjut dari supervisi akademik yang dilakukan kepala madrasah dan tim supervisor dilakukan dengan cara mengevaluasi guru-guru secara personal melalui pemanggilan ke ruang kepala madrasah dan secara berkelompok melalui rapat rutin. Dalam pelaksanaan evaluasi tersebut, akan disampaikan kekurangan setiap proses pembelajaran serta menjelaskan apa yang harus diperbaiki. Setelah dilaksanakan tahap tersebut, kepala madrasah melalui wakilnya melakukan pengontrolan setiap hari dengan cara mendatangi kelas-kelas untuk mengecek kehadiran guru-guru setiap kelasnya dan dilakukan sehari 3x yaitu setiap pagi, setelah istirahat dan selesai melaksanakan shalat Dhuhur. Hal ini dilakukan untuk mengoptimalkan proses pembelajaran, sehingga proses pembelajaran yang diharapkan dapat tercapai

Evaluasi pelaksanaan supervisi memberikan manfaat bagi kepala madrasah dan guru. Kepala madrasah dapat mengetahui sejauh mana target yang sudah dicapai dalam pelaksanaan peningkatan kemampuannya. Guru juga 
diharapkan dapat menerima hasil evaluasi secara terbuka, dan menerima saran serta arahan dari kepala madrasah atau supervisor untuk perbaikannya.

Untuk menindaklanjuti hasil temuan peneliti, kepala madrasah menganalisis dan mengevaluasi semua temuan-temuan dari hasil observasi terhadap kegiatan pelaksanaan pembelajaran guru baik menyangkut kelengkapan perangkat pembelajaran maupun jalannya pelaksanaan kegiatan pembelajaran siswa di kelas.

\section{Faktor Pendukung dan Penghambat Supervisi Akademik}

Dalam melaksanakan suatu kegiatan pelaksanaan supervisi akademik untuk meningkatkan mutu pembelajaran di suatu madrasah, pasti ditemukan beberapa kendala atau hambatan dalam pelaksanaan tersebut, hal ini ditunjukkan agar pihak madrasah bisa mengantisipasi dan mengambil tindakan dalam hal tersebut, dan tidak ketinggalan apa saja yang menjadi faktor pendukungnya agar pihak madrasah bisa mengetahui apa saja yang bisa menjadikan implementasi supervisi yang dilakukan kepala madrasah untuk meningkatkan mutu pembelajaran.

Terdapat beberapa faktor pendukung dan penghambat dalam hasil analisis implementasi supervisi akademik untuk meningkatkan mutu pembelajaran di MAN 2 Ciamis. Adapun rincian hasil wawancara dan pengembangan hasil temuan peneliti dari tiap-tiap faktor internal dan eksternalnya adalah faktor pendukung diantaranya pertama, kegiatan supervisi akademik yang sudah terjadwal dan teragendakan membantu pelaksanaan supervisi di MAN 2 Ciamis dalam meningkatkan proses pembelajaran di kelas. Adanya kemauan, komitmen dan dedikasi yang tinggi dari guru-guru dalam meningkatakan kompetensi dalam mengajar. Kedua, dengan adanya persiapan yang matang dari para guru sebelum disupervisi, sehingga dapat memudahkan kepala madrasah dalam melakukan supervisi akademik terhadap guru tersebut. Ketiga, tuntutan fikiran para guru yang ingin selalu berkembang dan mau mengikuti pergerakan dunia pendidikan, inilah yang dijadikan motivasi para guru dalam mengembangkan kompetensinya sehingga mutu pembelajaran selalu meningkat. Keempat, adanya kerja sama yang aktif dengan berbagai instansi baik Kementerian Agama, Dinas Pendidikan dan Universitas yang ada sehingga memudahkan pelaksaan supervisi di MAN 2 Ciamis. Dan kelima, dengan adanya sarana prasarana yang lengkap di dalam kelas membantu guru dalam proses pembelajaran di dalam kelas.

Dari beberapa faktor pendukung di atas dapat peneliti ambil kesimpulan bahwasanya dengan adanya pelaksanaan implementasi supervisi akademik dapat membantu meningkatkan mutu pembelajaran dan memperlancar proses pembelajaran di kelas. Hal ini di dukung dengan input guru yang baik dan fasilitis yang memadai, dan itu semua berjalan karena adanya komitmen yang tinggi dari guru-guru yang ada di MAN 2 Ciamis.

Sedangkangkan faktor penghambat yaitu pertama, pelaksanaan supervisi akademik belum berjalan dengan lancar sesuai dengan jadwal, karena adanya kesibukan dari kepala madrasah dan tim supervisor untuk mengadiri acara atau kegiatan diluar madrasah. Kedua, kurangnya tindak lanjut dari kepala madrasah setelah dilakukannya supervisi, mengakibatkan pelaksanaan supervisi tersebut kurang efektif. Ketiga, dengan pelaksanaan supervisi yang hanya setahun 2x 
dalam setiap semester menyebabkan kegiatan ini masih kurang efektif dalam meningkatkan mutu pembelajaran guru-guru. Keempat, tidak adanya literatur dan kurangnya buku penunjang khusus untuk guru, sehingga guru merasa kesulitan untuk mencari sumber pelajaran selain dari buku mapel, dan itu yang terkadang menghambat perkembangan ilmu pengetahuan bagi guru di madrasah. Kelima, keterbatasan alat praktikum yang dimiliki madrasah, mengakibatkan pelaksanaan proses pembelajaran bagi peserta didik hanya sebatas melakukan konsep teorinya saja tanpa melakukan praktik. Dan keenam, masih kurangnya pemahaman sebagian guru akan arti penting dalam penyusunan buku guru setelah disupervisi sehingga dalam penyusunan buku guru tersebut masih asal-asalan saja.

Dari beberapa faktor penghambat di atas dapat peneliti ambil kesimpulan bahwa pelaksanaan supervisi akademik dalam meningkatkan mutu pembelajaran belum berjalan dengan lancar sesuai dengan jadwal, hal ini disebabkan karena adanya kesibukan kepala madrasah dalam hal pembagian waktu sehingga tindak lanjut setelah diadakannya supervisi menjadi terhambat. Selain itu sebaiknya kepala madrasah lebih melengkapi lagi fasilitas dan alat praktikum serta literatur buku penunjang bagi guru dan peserta didik guna memperlancar dalam proses pembelajaran di kelas.

\section{SIMPULAN}

Kepala MAN 2 Ciamis dalam melaksanakan supervisi akademik terlebih dahulu dengan menyusun program perencanaan tahunan maupun semester. Menyusun program supervisi yang dimulai dari merencanakan, melaksanakan, dan melaporkan hasil supervisi akademik. Agar kepala madrasah dapat melaksanakan kegiatan supervisi sesuai jadwal, maka kepala madrasah harus memiliki kompetensi membuat program supervisi akademik. Pelaksanaan supervisi akademik dimulai dengan memeriksa program pembelajaran yang dimiliki guru. Selanjutnya kepala madrasah memberi jadwal kapan beliau akan melaksanakan supervisi atau kunjungan kelas untuk mengamati performa guru dalam melaksanakan tugas mengajarnya di dalam kelas. Kemudian akan ada pertemuan individual antara kepala madrasah dan guru untuk mendiskusikan hasil supervisi yang diperoleh kepala madrasah. Hal yang dibahas meliputi kelebihan dan kekurangan yang dimiliki guru, dan selanjutnya memberikan saran dan solusi terbaik untuk memperbaiki dan meningkatkan kualitas guru yang bersangkutan. Evaluasi supervisi akademik di lakukan adalah untuk melihat apakah suatu program yang telah direncanakan telah tercapai atau belum, atau untuk dapat melihat hasil tingkat efisiensi pelaksanaan supervisi yang di lakukan oleh kepala madrasah terhadap guru. Evaluasi supervisi akademik juga menilai hasil kinerja guru sebagai bahan pertimbangan untuk perbaikan ke arah yang lebih baik. Tindak lanjut dilakukan dapat berupa penguatan dan penghargaan diberikan kepada guru yang telah memenuhi standar, teguran yang bersifat mendidik diberikan kepada guru yang belum memenuhi standar dan guru diberikan kesempatan untuk mengikuti pelatihan-pelatihan. Faktor pendukung pendukung supervisi di MAN 2 Ciamis itu relatif, untuk perangkat supervisi diantaranya yaitu komponen-komponennya sudah lengkap mulai dari dikasih kalender pendidikan, silabus, dan guru hanya perlu melengkapi kekurangan yang 
tersisa, mulai dari kertas, printer, laptop, hampir diberikan fasilitas lengkap. Sedangkan faktor penghambat nya yaitu kadangkala guru merasa tidak nyaman jika mendengar kata-kata supervisi, karena guru merasa terbebani dengan adanya supervisi atau pengawasan. Oleh sebab itu, perlu dibangun komunikasi yang baik antara guru dan kepala madrasah.

\section{REFERENSI}

Anissyahmai, Rohiat, \& Juarsa, O. (2017). Supervisi Akademik Kepala Sekolah. MAPEN: $\quad$ Jurnal Manajer 11. https://ejournal.unib.ac.id/index.php/manajerpendidikan/article/view/3201

Dibyantoro, S. S. (2017). Manajemen Supervisi Akademik Untuk Meningkatkan Kinerja Guru Mata Pelajaran Pendidikan Jasmani dan Kesehatan SMK di Kecamatan Sewon Kabupaten Bantul. Utile: Jurnal Kependidikan, 3(2). https://doi.org/10.37150/jut.v3i2.69

Jahari, J. (2013). Manajemen Madrasah. Alfabeta.

Leniwati, L., \& Arafat, Y. (2017). Implementasi Supervisi Akademik Kepala Sekolah Untuk Meningkatkan Kinerja Guru. JMKSP (Jurnal Manajemen, Kepemimpinan, dan Supervisi Pendidikan), 2(1). https://doi.org/10.31851/jmksp.v2i1.1158

Maralih, M. (2014). Peranan Supervisi Dalam Peningkatan Kualitas Pendidikan. QATHRUNA: Jurnal Keilmuan dan Pendidikan Islam, 1(1). http://jurnal.uinbanten.ac.id/index.php/qathruna/article/view/251

Messi, M., Sari, W. A., \& Murniyati. (2018). Pelaksanaan Supervisi Akademik Pengawas Sekolah Sebagai Upaya Pengingkatan Profesionalsime Guru. JMKSP (Jurnal Manajemen, Kepemimpinan, dan Supervisi Pendidikan), 3. https://jurnal.univpgripalembang.ac.id/index.php/JMKSP/article/view/1583

Mustafid, D., Ibrahim, S., \& Khairuddin. (2016). Supervisi Akademik Kepala Madrasah Dalam Meningkatkan Kinerja Guru Pada MIN 2 Kota Takengon Kabupaten Aceh Tengah. Jurnal Administrasi Pendidikan, 4(2), 1-13.

Nabila, I. (2018). Kompetensi Supervisi Kepala Madrasah. Jurnal Isema : Islamic Educational Management, 3(1). https://doi.org/10.15575/isema.v3i1.3282

Nurfatah, \& Rahmad, N. (2018). Pelaksanaan Supervisi Oleh Kepala Sekolah Dan Pengawas Sekolah. JMKSP (Jurnal Manajemen, Kepemimpinan, dan Supervisi Pendidikan), 3(1). https://jurnal.univpgripalembang.ac.id/index.php/JMKSP/article/view/1585

Prasojo, L. D., \& Sudiyono. (2015). Supervisi Pendidikan. Gava Media.

Sagala, S. (2012). Supervisi Pembelajaran Dalam Profesi Pendidikan. Alfabeta. Subaidi. (2019). Manajemen Biaya dan Sarana Prasarana Di SMAN 3 Pati dan MA Silahul Ulum Asempapan Trangkil Pati. Jurnal At-Tarbiyat: Jurnal Pendidikan Islam, 2(1), 69-87.

Syukri, Harun, C. Z., \& Usman, N. (2015). Pelaksanaan Supervisi Akademik Kepala Sekolah Untuk Meningkatkan Kinerja Guru Sekolah Dasar Pada Gugus I UPTD Dewantara Aceh Utara. Jurnal Administrasi Pendidikan Pascasarjana Universitas Syiah Kuala, 3(2). http://www.jurnal.unsyiah.ac.id/JAP/article/view/2561

Zulfikar, Yusrizal, \& Ibrahim, S. (2017). Supervisi Akademik Oleh Kepala Sekolah Dalam Meningkatkan Kompetensi Profesional Guru SD Negeri 2 Calang 
N. Abdurohim, A. Iskandar

Kabupaten Aceh Jaya. Jurnal Administrasi Pendidikan Pascasarjana Universitas Syiah Kuala, http://www.jurnal.unsyiah.ac.id/JAP/article/view/9354 $5(3)$. 